\title{
GEOGRAPHY OF WASTE AS A NEW APPROACH IN WASTE MANAGEMENT STUDY
}

\author{
Florin-Constantin Mihai $^{1}$
}

\begin{abstract}
Municipal waste management in the last two decades has become a global environmental priority in the context of increasing amounts of waste generated due to the development of a mass consumer society. Various issues of waste management, territorial and temporal variability, spatial analysis of treatment or disposal facilities, systemic implications on the environment, the harmonization of international policy at national, regional and local level are solid arguments for studying this field by geography. Mostly technical or economic studies, lacking a vision of territory are supplemented in the conceptual and methodological level by geographers. This paper performed on the one hand, an overview of various approaches in current literature on waste management issue and on another hand analyses the geographical contributions in this field. Our conclusions lead to the idea that waste management must be performed according to the geographical features of the territory concerned.
\end{abstract}

Keywords: waste management, interdisciplinarity, geography of waste

\section{Introduction}

Municipal waste management is obviously a multidisciplinary and interdisciplinary research, scientific papers are treated preponderantly by engineers, chemists, physicists, economists, but more recently also by geographers, sociologists, lawyers and psychologists. Thus, the scientific community is increasingly interested in waste management study, each field contributing by its own methodology to the understanding of this issue.

\section{Waste management - multi and interdisciplinary approaches}

Two methodological tools regarding waste management assessment studies were drafted in the scientific specific literature:

$\checkmark$ Life Cycle Assessment (LCA studies) an environmental engineering approach, analyzing the various methods and technologies used in waste management in terms of indicators on resulting emissions $\left(\mathrm{CO}_{2}\right.$ and $\mathrm{VOC}$, dust and powder) power consumption, environmental issues involved etc : Cherubini et al. (2008), Rojas et al.(2008)

$\checkmark$ Cost-benefit analysis ( CBA - studies) which considers comparison and modeling of the costs for various waste management options in order to assure an effective

\footnotetext{
1 "Al.I.Cuza" University of Iasi, Faculty of Geography and Geology, Department of Geography, Bd.Carol I 20A, 700505, Iasi, Romania, mihai.florin86@yahoo.com
} 
management of public and private expenditures for this sector - Bohma et al. (2010), Bel et al.(2009)

Also, some assessments are based on the LCA and CBA studies or analyzed from a systemic perspective (Eriksson et al. 2005). Pires et al.(2011) have reviewed other assessment tools used in waste management such as:

- management information system (MIS)

- decision support system (DSS)

- $\quad$ expert system (ES),

- $\quad$ scenario development (SD),

- material flow analysis (MFA),

- $\quad$ environmental impact assessment (EIA),

- $\quad$ strategic environmental assessment (SEA)

- socioeconomic assessment (SoEA),

- $\quad$ sustainable assessment (SA)

- $\quad$ adding systems engineering models such as : forecasting models (FM), simulation odels (SM), optimization models (OM) and integrated modeling system (IMS).

Comparing the relative distribution between groups of models and tools for systems analysis, the most common practices for waste management in European countries are those using various systems assessment tools rather than system engineering models (Pires et al, 2011). Furthermore, social sciences propose a new methodology for social impact assessment (SIA - studies) arguing that an effective technical system does not provide good functionality of waste management system if it is not supported by the local community or the people directly involved in this area (employees). In this case, protests, public demonstrations, strikes, issues of governance may appear (Mengozzi, 2010; Wolsink, 2010). Also, psychology has an approach on positive or negative behaviour of individuals in relation to waste management: Swami et al. (2011), Knussen et al. (2004).

Waste prevention has become a primary target in the concept of waste hierarchy that actually means a prioritization of the policies for prevention, reuse, recycling, treatment and incineration with energy recovery, incineration and less landfills schemes. First of all, waste generation per capita is the starting point in assessing the waste management systems. Beigl et al. (2008) inventoried and analysed 45 municipal waste generation models; in most cases, economic and socio-demographic parameters were found significant in explaining variation of their generation.

Along with waste generation indicator, waste composition is another significant factor in implementation of a waste management system. Municipal waste compositions studies (Gidarakos et al.2006;Burnley et al. 2007) can help policy makers in adopting a certain methods of treatment and recovery or in last case, waste disposal facilities. Based on data regarding waste generation and composition, predictions regarding the evolution of recyclable waste amounts can be made, by adapting the current waste management policies (Sokka et al., 2007).

\section{Geography of waste as new branch in geographical field}

The first geographical approach of waste management issue has been performed in 1972 by Jean Gouhier in PhD thesis - Eléments pour une géographie des déchets : essai d'inventaire et analyse comparée dans le Maine et la Région de Liège, Caen University, 
developing this topic in the French school. Although it was a new subfield in geographical research, this issue has often been ignored.

The main research pioneers in this direction were: Jean Gouhier setting up a new discipline - rudology (systemic study of waste management), creating Rudology Institute at the University of Maine (Le Mans) that leads him since 1990 and Albert Tauveron from University of Grenoble (Perris, 2004). Gradually, the waste issue has become increasingly discussed in numerous international and national environmental policies.

Its territorial implications became obvious increasingly growing interest of geographers to this research direction, being outlined the geography of waste. In the French school, this branch studies the influences of socio-economic level on waste management services (collection systems, transport, recovery and disposal) and their implications for territorial planning. Most technical or economic studies (lacking a vision of the territory) are conceptual and methodological works are supplemented by geographers such as Gouhier (2000), Tabeaud and Hamez (2000).

Waste management becomes a research direction in geographical Phd studies : Kah (2000), N'kounkou (2000), Brischoux (2001), Perrin (2004), Campan (2007).

Major issues of waste management in developing countries and its implications on the environment have drawn the attention of geographers in particular on the African continent, in the development of case studies for different regions or cities such as Mombo and Edou (2005), Meunier (2007), El Abidinesy (2009), Firdaus and Ahmad (2010), Mboumba (2011). In general, geographical approach on waste management is achieved by quantitative and/or qualitative ways (Perris, 2004). Thus, geographical contributions to the study of waste management are:

1.A quantitative approach - spatial analysis of waste management infrastructure (collection, transport, recovery and disposal facilities) and its implications on territorial planning and environment by using thematic cartography, GIS, satellite imagery (remote sensing) spatial analysis at national, regional and local level of waste management indicators (multiscale analysis), spatio-temporal anaysis, achievement of statistical database for various geographical regions, geosystemic approach of environmental implications.

Geographical contributions are brought regarding methods for estimating the quantities of waste according to different demographic and socio-economic parameters Gregg (2010), Kah (2003) or Desmond (2009) regarding the strategic environment assessment (SEA studies). Le Dorlot (2004) insists on territorial approach of household waste management without which it cannot implement the national and international policies and objectives at the local level. Geographical analysis contributes to understanding the space dedicated to waste management and technical solutions should adapt to the territory concerned (Perris, 2004).

2.Qualitative and social approach - which analysis the behaviour of urban and rural communities to waste management options (NIMBY policy for example), the transition from a traditionally system (sometimes rudimentary) based on non-compliant landfills to an integrated waste management systems which aims prevention, recycling and waste recovery. Such a transition involves behavioural changes by all social actors. In this regard, Bertrand and Laurent (2003) aim the development of policies, structures, behaviours regarding waste management, from collection of mixed waste and non-compliant landfills, to waste incinerators and selective collection points from today as well as these changes reflected in the territory, practices and attitudes. This social approach which studies the behaviour of communities towards waste management and also involves issues of territorial governance is debated by Davies (2008) in The Geographies of Garbage Governance: Interventions, 
Interactions and Outcomes. Also, Davies et al.(2005), Fahy and Davies (2007), suggests an approach to investigate attitudes towards waste management and especially the crucial change of these attitudes through active participation of residents to minimize waste in Ireland (state with high waste generation per capita and landfilled from EU27). Involving local communities in the process of recycling or waste recovery may lead to improved living conditions and social inclusion (Tremblay et al., 2010; Tudor et al., 2007). On the other hand, so-called informal sector recyclers play an important role in the recovery of waste in developing countries (Nzeadibe, 2009, Mitchell 2008). Social and territorial implications should not be ignored. Civil society should take part in decisions on implementing waste management systems (Davies, 2003). Thus, waste management cannot be approached only from technical and economic reasons, as it requires a holistic approach (Seadon, 2006).

\section{conditions \\ 4. Geography of waste and/or waste management related to geographical}

The data regarding waste management must be related to socio-economic and natural conditions of the territory concerned (Le Dorlot, 2004; Passarini et al., 2011). Each territory has its own particular framework and dynamics determined by its climate, its people, its infrastructure, and its power legacies (Mengozi, 2009).

In the LCA studies, the geographic specificity and design of the selected waste management systems tend to be less important than the evaluation of a model, a technical process or a philosophical hypothesis such as waste hierarchy. (Cleary, 2009). Waste hierarchy often appears to be a principle based on dogmatic claims, which probate geographical complexity to one ideal way (Mengozzi, 2010).

Disparities regarding the economic and living standards between the EU member states of Northern and Western Europe compared to the Southern and Eastern Europe are reflected in municipal solid waste management (MSW) systems (Mihai and Apostol, 2012). Also, the Asian continent is a mixture of complex cultures, a mix that is truly reflected in the MSW systems. (Shekdar, 2009). Geographical distribution of the demographic and socioeconomic indicators influences the generation of municipal waste in a country, region or county.

In general, population density (or urban population) is likely to have a positive impact on waste generation and only economies of scale spurred by urbanisation could invert the trend and reduce collection where density is higher (Mazzanti and Roboli, 2008).

In developing countries, waste statistics are based on estimations due to the lack of waste weighing schemes. Kumar et al. (2009), based on the number of trips/day of waste collection services from different wards/zones of the city, determined the amounts of waste collected from various Indian cities. They also computed the waste generation rate in terms of $\mathrm{kg} / \mathrm{capita} /$ day according to the population of these cities.

The waste generated in the developing countries is similar in composition, the variation between regions being dictated by the climatic, cultural and industrial, infrastructural and legal factors (Khajuria et al, 2010). Waste composition is also influenced by geographical location, the population's standard of living and energy source (Ngoc and Schnitzer, 2009).

Geographical conditions from a specific country, region, city or village put their mark on waste management systems even more as these are poorly developed. Thus, in terms of low population served by sanitation services and poor infrastructure, the waste generated and uncollected is disposed in open dumps polluting the local environment. In developing countries, all the explanatory variables including economic factors, social characteristics and 
geographical barriers are found to influence municipal solid waste disposal significantly (Chen, 2010). Also, new EU members have a low share of access of rural population to sanitation services leading to illegal dumping. Location of these rural dumpsites varies depending on the proximity of human settlements and local landscape. Apostol and Mihai (2012) analysed the disparities between Romanian counties regarding the rural population access to sanitation services from 2008 which reflected the geographical distribution of statistical data concerning rural landfills from 2009 (having as deadline for closure and rehabilitation July $16^{\text {th }}$ ).

Mihai and Lamasanu (2011) revealed that physical-geographical transition of Neamt County (mountains - subcarpathian depressions - hills - corridor valley - plateau) influenced the spatial analysis of landfills volumes from rural areas (communes level), these data being correlated with rural population density. Waste management from Romanian rural areas continues to be a major environmental issue and local authorities have difficulties in fulfilling the acquis communautaire. (Apostol and Mihai,2011; Lamasanu si Mihai, 2011). Also, in urban areas the population is not fully covered with waste collection services which often lead to illegal dumping.

Mihai et al., (2011) outlined regional disparities concerning the amounts of urban waste generated and uncollected (estimated values) allowing an assessment of vulnerability to waste dumping. Marques and Simoes (2008) examine the improvement of urban waste market structure in Portugal and show its geographical distribution at regional level. In Italy, the instruments' effectiveness in driving waste generation reductions is explained by economic, policy and structural geographical differences (Mengozzi and Zoboli, 2008). Furthermore, Passarini et al. (2011) studied the waste generation and collection rates for various settlements from Emilia Romagna region (including urban and rural areas) these municipalities being classified according to their altitude and population density. Their result shows that the highest separate collection are in the plain (22 out of 25 municipalities), and the lowest performance of waste generation and separate collection are in the mountains and hills.

For district level, Purcell and Magette (2009) propose a model for prediction of biodegradable waste from households and commercial in the Dublin region, providing a geographical view concretised through thematic maps of electoral divisions. Also highincome countries are facing illegal dumping. Ichinose and Yamamoto (2011) reveal the geographic features of illegal dumping from Japan, correlating the GDP per capita regional income from 2005 with total number of illegal dumps from 1997 to 2006 (frequency) completed with an econometric model.

Some EIA studies of landfill sites uses geographic tools such as GIS techniques and thematic cartography (Leao et al.2004; Sumathi et al., 2008) or remote sensing through satellite image processing (Son et al., 2011). Furthermore, GIS techniques are used to design and analyse the collection and transportation routes of MSW systems from urban, metropolitan or rural regions. Transportation depends on organisational and geographical aspects representing the characteristics of the territory concerned such as the size, topography, streets infrastructure etc. (Salhofer et al.2007)

\section{Conclusions}

Technical and economic approaches of waste management still prevail in current literature. However, social, environmental and territorial implications impose a holistic approach to this issue. In this context, geography as a science of the interface between natural and social systems may contribute to improving waste management systems by taking into 
account the natural, socio-economic and demographic features of the territory concerned. Geographical contributions in the understanding of this issue begin to increase.

\section{References}

1. Apostol L., Mihai F.C., 2012. Rural waste management : challenges and issues in Romania, Present Environement and Sustainable Development, 6 (1), in press

2. Apostol, L., Mihai, F.C., 2011. The process of closing down rural landfills Case study : Neamț county, Present Environment and Sustainable Development, 5 (2), 167- 174

3. Beigl, P., Lebersorger ,S., Salhofer, S., 2008. Modelling municipal solid waste generation: A review, Waste Management, 28 , 200-214

4. Bel,G., Mur, M., 2009. Intermunicipal cooperation, privatization and waste management costs: Evidence from rural municipalities, Waste Management, 29, 2772-2778

5. Bertrand, J.R.,. Laurent, F., 2003. De la décharge à la déchetterie: Questions de géographie des déchets. Collection Géographie sociale. Rennes : Presses universitaires de Rennes,

6. Bohma, R A., Folz, D. H,. Kinnaman,T. C,, Podolsky, M. J., 2010. The costs of municipal waste and recycling programs, Resources, Conservation and Recycling, 54,864-871

7. Burnley,S.J,.Ellis,J.C.,Flowerdew,R,Poll,A.,J., Prosser,H., 2007. Assessing the composition of municipal solid waste in Wales, Resources, Conservation and Recycling ,49,264-283

8. Campan,F., 2007. Le traitement et la gestion des déchets ménagers à la Réunion : approche géographique., Université de la Réunion, Thèse de doctorat

9. Chen,C.C., 2010. Spatial inequality in municipal solid waste disposal across regions in developing countries. Int. J. Environ. Sci.Tech., 7 (3), 447-456.

10. Cherubini, F., Bargigli,S., Ulgiati, S., 2008. Life cycle assessment of urban waste management: Energy performances and environmental impacts. The case of Rome, Italy, Waste Management 28 , 2552-2564

11. Cleary,J., 2009. Life cycle assessments of municipal solid waste management systems: A comparative analysis of selected peer-reviewed literature, Environment International, $35,1256-1266$

12. Davies, A., 2008. The Geographies of Garbage Governance: Interventions, Interactions and Outcomes. Aldershot: Ashgate

13. Davies, A.,Fahly,F., Taylor,D., 2005. Mind the gap! Householder attitudes and actions towards waste in Ireland, Irish Geography,3, 151-168

14. Davies, A., 2003. Waste wars- public attitudes and the politics of place in waste management strategies,Irish Geography, Vol36(1), 77-92.

15. El Abidinesy, Z., 2009. Géographie urbaine de l'insalubrité. Le cas de Saint-Louis du Sénégal. Paris: L'Harmattan,

16. Eriksson O, Carlsson Reich M, Frostell B, Björklund A, Assefa G, Sundqvist J-O, 2005. Municipal solid waste management from a systems perspective, Journal of Cleaner Production $13,241-$ 252

17. Fahy,F.,Davies,A., 2007. Home improvements: Household waste minimisation and action research ,Resources, Conservation and Recycling ,52,13-27

18. Firdaus, G ., Ahmad , A., 2010. Management of Urban Solid Waste Pollution in Developing Countries, Int.J. Environ. Res., 4,795-806,

19. Gidarakos,E.,Havas, G., Ntzamilis,P., 2006. Municipal solid waste composition determination supporting the integrated solid waste management system in the island of Crete, Waste Management ,26, 668-679

20. Gouhier J., 2006. Au-delà du déchet, le territoire de qualité : Manuel de rudologie, Le Havre, Presses Universitaires de Rouen et du Havre,

21. Gouhier J., 1972. Eléments pour une géographie des déchets : essai d'inventaire et analyse comparée dans le Maine et la Région de Liège,Universite de Caen, Thèse de doctorat 
22. Kah,E.,2003. La méthode d'évaluation contingente appliqué aux déchets urbains, L'Espace géographique, $1,47-59$

23. Kah., E.,2000. Un problème de préservation de l'environnement en géographie : l'élimination des déchets ménagers. L'exemple du consentement à payer", Thèse de doctorat, Université Louis Pasteur, Strasbourg

24. Khajuria, A., Yamamoto Y., Morioka, T., 2010. Estimation of municipal solid waste generation and landfill area in Asian developing countries, Journal of Environmental Biology, 31(5) ,649-654

25. Knussen, C., Yule, F., MacKenzie,J., Wells, M., 2004. An analysis of intentions to recycle household waste: The roles of past behaviour, perceived habit, and perceived lack of facilities, Journal of Environmental Psychology ,24,p 237-246

26. Kumar S., Bhattacharyya, J.K., Vaidya, A.N., Chakrabarti, T., Devotta,S., Akolkar, A.B., 2009. Assessment of the status of municipal solid waste management in metro cities, state capitals, class I cities, and class II towns in India: An insight, Waste Management ,29, 883-895

27. Le Dorlot,E., 2004. Les déchets ménagers : pour une recherche interdisciplinaire , Strates , 11 ,110, mis en ligne http://strates.revues.org/410

28. Lămaș anu A., Mihai F.C.,The illegal dumping of waste in forest areas. Evidence from rural territory., In:Integrated Management of Environmental Resources, International Conference, Suceava,Romania, November 4-6th 2011,Proceedings in print

29. Leao, S., Bishop, I., Evans, D., 2004. Spatial-temporal model for demand and allocation of waste landfills in growing in urban regions , Computers, Environment and Urban Systems ,28 ,353385

30. Marques R.C., Simoes.P., 2008. Does the sunshine regulatory approach work? Governance and regulation model of the urban waste services in Portugal, Resources, Conservation and Recycling ,52,1040-1049

31. Masocha, M., 2006. Informal waste harvesting in Victoria Falls town, Zimbabwe:Socio-economic benefits, Habitat International 30 ,pp. 838-848

32. Mazzanti, M., Zoboli R., 2008. Waste generation, waste disposal and policy effectiveness Evidence on decoupling from the European Union, Resources, Conservation and Recycling, 52 ,12211234

33. Mengozzi, A., 2010. Waste Growth Challenges Local Democracy. The Politics of Waste between Europe and the Mediterranean: a Focus on Italy, California Italian Studies Journal, 1(1),1-21 (http://escholarship.org/uc/item/53v28242)

34. Meunier,N.A., 2007. Géographie d'une ville à travers la gestion des déchets, Ouagadougou (Burkina Faso) in Mappemonde, nr 83 (3) htpp://mappemonde.mgm.fr/num15/articles/art07305.html

35. Mihai, F.C., Apostol,L., 2012. Disparities in municipal waste management across EU-27. A geographical approach, Present Environement and Sustainable Development, 6 (1), in press

36. Mihai,F.C., Lămăşanu,A., Spatial analysis of landfills volumes from rural territory Case study:Neamt County,Romania, In: Proceedings of the International Conference Environment Landscape - European Identity, November 4-6, 2011, Bucharest, Romania,

37. Mihai, F.C., Ghiurca A., Lamasanu A., 2011. Estimation of urban waste generated and uncollected in Romania, Analele Universitati Oradea, Fascicula:Protectia Mediului, vol XVI, $(B)$

38. Mitchell,C.,L., 2008. Altered landscapes, altered livelihoods: The shifting experience of informal waste collecting during Hanoi's urban transition, Geoforum ,39, 2019-2029

39. Mombo, J.B.,Edou, M. 2005. La gestion des déchets solides urbains au Gabon, Geo-Eco-Trop, 2005, 29, pp. 89-100

40. Ngoc, U. N., Schnitzer, H., 2009. Sustainable solutions for solid waste management in Southeast Asian countries, Waste Management ,29,1982-1995

41. N'kounkou,U., 2000. Gestion territoriale des ordures ménagères franciliennes - le gisement des ordures ménagères, leurs espaces de production : vers une minimisation du flux résiduel. Université du Maine, thèse de doctorat. 
42. Passarini,F.,Vassura,I., Monti, F., Morselli. L., Villani, B., 2011. Indicators of waste management efficiency related to different territorial conditions, Waste Management, 31, 785-792

43. Perrin, N., 2004. Approche globale des besoins en informations des collectivités locales dans le domaine de la gestion des déchets ménagers. Essai d'une analyse spatiale sur les villes de Grenoble, Vitry-Sur-Seine et de la Communauté d'Agglomération du Pays Voironnais, Thèse de doctorat ,l'Université Joseph Fourier - Grenoble

44. Pires,A.,Martinho,G.,Chang, N.B., 2011. Solid waste management in European countries: A review of systems analysis techniques, Journal of Environmental Management ,92,1033-1050

45. Purcell ,M.,Magette, W.L.,2009,Prediction of household and commercial BMW generation according to socio-economic and other factors for the Dublin region, Waste Management ,29,1237-1250

46. Rojas ,C.R.I.,Zambrano,C.E.A., 2008. Urban observatories opportunities for environmental monitoring: Solid wastes, Waste Management ,28, 540-544

47. Salhofer, S., Obersteiner,G., Schneider, F., Lebersorger, S., 2008. Potentials for the prevention of municipal solid waste, Waste Management, 28 , 245-259

48. Salhofer, S., Schneider,F., Obersteiner, G., 2007. The ecological relevance of transport in waste disposal systems in Western Europe, Waste Management, 27, 47-57

49. Seadon.,J.,K.,2006, Integrated waste management - Looking beyond the solid waste horizon , Waste Management, 26, 1327-1336

50. Shekdar, A.V., 2009. Sustainable solid waste management: An integrated approach for Asian countries ,Waste Management, 29, 1438-1448

51. Sokka,L., Antikainen,R., Kauppi,P.E., 2007. Municipal solid waste production and composition in Finland-Changes in the period 1960-2002 and prospects until 2020, Resources, Conservation and Recycling, 50,475-488

52. Son,S.,Wang, M., Shon,J.K., 2011. Satellite observations of optical and biological properties in the Korean dump site of the Yellow Sea, Remote Sensing of Environment, 562-572

53. Sumathi,V.R., Natesan, U., Sarkar, C., 2008. GIS-based approach for optimized siting of municipal solid waste landfill, Waste Management, 28 ,2146-2160

54. Swami,V., Premuzic C.T., Snelgar, R., Furnham, A., 2011. Personality, individual differences, and demographic antecedents of self-reported household waste management behaviours, Journal of Environmental Psychology, 31, 21-26

55. Tabeaud, M., Hamez,G., 2000. Les métamorphoses du déchet, Paris, Publications de la Sorbonne,

56. Tremblay, C.,Gutberlet, J., Peredo, A. M., 2010. United We Can: Resource recovery, place and social enterprise, Resources, Conservation and Recycling , 54, 422-428

57. Tudor, T.L., Barr, S.W., Gilg, A.W., 2007. Linking intended behaviour and actions: A case study of healthcare waste management in the Cornwall NHS, Resources, Conservation and Recycling, 51,1-23

58. Wolsink.,M., 2010. Contested environmental policy infrastructure: Socio-political acceptance of renewable energy, water, and waste facilities, Environmental Impact Assessment Review, 30, 302-311 